The interaction effect of economic freedom and democracy on corruption: a panel cross-country analysis

\author{
Shrabani Saha, Rukmani Gounder \\ Department of Economics and Finance \\ Massey University \\ Palmerston North \\ New Zealand \\ and \\ Jen-Je Su \\ Department of Accounting, Finance and Economics \\ Griffith University \\ Australia \\ Corresponding author: \\ Rukmani Gounder \\ Department of Economics and Finance \\ Massey University \\ Palmerston North \\ New Zealand \\ Phone: 64 (6) 3505969 \\ Fax: 64 (6) 3505660 \\ R.Gounder@massey.ac.nz
}

\begin{abstract}
This paper examines the effects of economic freedom, democracy and its interaction term on controlling corruption. The results indicate that interaction between economic freedom and democracy has a significant impact on combating corruption. Partial effect analysis shows that economic freedom reduces corruption in any political environment, and the effect is substantially greater with a higher-level of democracy. In contrast democracy increases corruption when the level of economic liberalization is low, however, once past the threshold level corruption is substantially lower with full economic freedom.
\end{abstract}

Keywords: Democracy, Economic freedom, Corruption, Panel data

JEL classification: C23; K42; O50 


\section{The interaction effect of economic freedom and democracy on corruption: a panel cross-country analysis}

\section{Introduction}

In defining the causes of corruption, economists have argued that lack of competition fosters corruption. The focus on competition and its impact on corruption have been noted in two different perspectives. One is political liberalization or democratization and the other is economic liberalization or decentralization. Competition between public officials reflects democratization that includes political rights, civil liberties and press freedom, whereas economic competition fosters economic liberalisation that reflects the degree of government intervention in a country. In this paper we evaluate the impact that democracy and economic freedom have on the existing level of corruption and its interactive effect in 100 countries.

In many market-oriented economies government restrictions on economic activity give rise to rents in various forms, and people often compete for the rents (Krueger, 1974) thus giving rise to varying degrees of corruption. ${ }^{1}$ Like competition between firms, competition can also take place between government officials who possess the discretionary power to deliver public goods. Rose-Ackerman (1978) first suggested that competition between officials keep the level of bribe relatively low and may eliminate entirely due to the possibility of overlapping jurisdictions, i.e. low bribe returns and the honesty of some officials may push the market-clearing bribe-price still lower, inducing other officials to give up corruption.

To explain the relationship between democratization and corruption several studies have used trade openness, government size, government intervention or composite economic freedom indices as the controlled variables (Treisman (2000), Tavares and Wacziarg (2001), Chowdhury (2004), Bohara et al. (2004), Shen and Williamson (2005), Goel and Nelson (2005)). On the other hand, studies by Ades and Di Tella (1999) and Fisman and Gatti (2002) on economic liberalization and corruption utilize political rights and/or civil liberties as the controlled variables. Furthermore, civil liberties act as an instrumental variable for describing the effect of corruption on competitiveness (Emerson, 2006).

\footnotetext{
${ }^{1}$ Other studies also support the view that greater state control leads to the possibility of high levels of corruption (Shleifer and Vishny, 1993; Mauro, 1997; Acemoglu and Verdier, 2000). Ades and Di Tella (1999) note that more competition in the economy reduces the level of profits or rents so that officials have less incentive to engage in corruption.
} 
By far, although most empirical findings confirm that democracy and economic freedom alone does reduce corruption, to the best of our knowledge, there is no cross-county study which captures the interaction effect of these two factors. Investigation of the interaction effect between democracy and economic freedom is vital since countries such as Hong Kong and Singapore show a very low level of democracy and at the same time have a very low level of corruption although there exists a very high level of economic freedom in these countries. On the other hand, in spite of India's high level of democracy it experiences a very high level of corruption but has a low level of economic freedom. Thus, it is of interest to ask how these two factors, i.e. democracy and economic freedom, work together in affecting corruption. Is it always true that democracy is a cure for corruption in any environment with different degrees of economic freedom? And, does economic freedom work more or less effectively in controlling corruption in an environment that enjoys more political freedom?

This study differs from earlier literature as we explicitly examine the interaction effect of democratization and economic freedom on corruption. Following Shen and Williamson (2005) the measure of democracy used here includes political rights, civil liberties and press freedom. This measure of democracy reflects the idea of broad democracy introduced by Barro (1999). Economic freedom index used in this study is a composite index that considers a broad view of economic variables in the business sector. ${ }^{2}$ Some studies have used trade openness and foreign direct investment to explain the effectiveness of economic openness in reducing corruption (see Larrain and Tavares, 2004). In a systematic examination of the hypothesis and extending the sample size from previous studies we quantify cross country panel estimations for 100 nations over the period 1995 to 2004.

\section{Data and models}

The study utilizes Transparency International's annual corruption perception index (CPI) as the dependent variable. ${ }^{3}$ The Freedom House reports subjective indices for political rights, civil liberties and media freedom that are used to construct democracy index. ${ }^{4}$ Economic freedom index is sourced from the Heritage Foundation. We rescale the ranking of CPI from

\footnotetext{
${ }^{2}$ Economic freedom index is a equally weighted index based on eight individual freedoms: business freedom, trade freedom, monetary freedom, freedom from government, fiscal freedom, property right, investment freedom and financial freedom. Freedom from corruption component is deleted to avoid the circular relationship problem with the dependent variable. See http://heritage.org/Index/ for details.

${ }^{3}$ The CPI measures the degree of corruption as seen by business people, academics and risk analysts. For details see http://www.transparency.org/policy_research/surveys_indices/cpi.

${ }^{4}$ See http://www.freedomhouse.org for details.
} 
0 (least corrupt) to 10 (most corrupt); and democracy (DEMO) and economic freedom (EF) indices on a scale of 0 to 10 , where maximum score indicates the highest level of freedom.

To measure what levels of democracy and economic freedom matter to influence corruption the following model is specified as:

$$
\begin{aligned}
\mathrm{CPI}_{\mathrm{i}, \mathrm{t}}= & \beta_{0}+\beta_{1} \mathrm{DEMO}_{\mathrm{i}, \mathrm{t}}+\beta_{2} \mathrm{EF}_{\mathrm{i}, \mathrm{t}}+\beta_{3} \mathrm{DEMO}_{\mathrm{i}, \mathrm{t}} * \mathrm{EF}_{\mathrm{i}, \mathrm{t}}+\beta_{4} \log (\mathrm{RGDP})_{\mathrm{i}, \mathrm{t}}+\beta_{5} \mathrm{GINI}_{\mathrm{i}, \mathrm{t}} \\
& +\beta_{6} \mathrm{UNEM}_{\mathrm{i}, \mathrm{t}}+\beta_{7} \mathrm{ALR}_{\mathrm{i}, \mathrm{t}}+\varepsilon_{\mathrm{i}, \mathrm{t}}
\end{aligned}
$$

where four socio-economic control variables are utilized, i.e. per capita real gross domestic product (RGDP), unemployment rate (UNEM), gini index (GINI) and adult literacy rate (ALR). ${ }^{5} \varepsilon$ is error term, $\mathrm{i}$ is country, $\mathrm{t}$ is time. The coefficient $\beta_{3}$ captures the interaction effect of democracy and economic freedom - which is the main focus in this study. In addition, the partial effects of democracy and economic freedom on corruption are computed as follows:

$$
\begin{aligned}
& \Delta \mathrm{CPI}_{\mathrm{i}, \mathrm{t}} / \Delta \mathrm{DEMO}_{\mathrm{i}, \mathrm{t}}=\beta_{1}+\beta_{3} \mathrm{EF}_{\mathrm{i}, \mathrm{t}} \\
& \Delta \mathrm{CPI}_{\mathrm{i}, \mathrm{t}} / \Delta \mathrm{EF}_{\mathrm{i}, \mathrm{t}}=\beta_{2}+\beta_{3} \mathrm{DEMO}_{\mathrm{i}, \mathrm{t}}
\end{aligned}
$$

If $\beta_{3}<0$, then equation (2a) implies that a one percentage point increase in democracy index yields a greater reduction in the level of corruption with a higher level of economic freedom. Similarly if $\beta_{3}<0$, then a one percentage point increase in economic freedom index in equation (2b) yields a greater reduction in the level of corruption with a higher level of democracy.

\section{Empirical evidence}

We examine the relationship of democracy, economic freedom and their interaction effect on corruption utilizing different estimation methods. First, the panel least squares (PLS) result (Table 1) of column (1) shows that democracy (DEMO), economic freedom (EF) and the interaction term are all significant at the $1 \%$ level. It suggests that interaction term has a significant impact on controlling corruption. The estimated democracy coefficient is positive

\footnotetext{
5 Data sources are Groningen Growth and Development Centre (2004) http://www.ggdc.net/index-dseries.html; The Political Risk Services Group (2004) East Syracuse, New York; World Bank (2005) World development indicators, data on CDROM, Washington, D.C.; World Institute of Development Economic Research (2004) World income inequality database, http://www.wider.unu.edu/wiid/wiid.htm
} 
while the estimated economic freedom and the interaction term coefficients are negative. The results of these two factors are interpreted in details in the partial effect analysis. The PLS estimated results in column (2) show that the sign and the significance levels of DEMO, EF and interaction term remain unchanged when the four socio-economic control factors (i.e. RGDP, ALR, UNEM, GINI) are incorporated. It indicates that RGDP per capita, higher employment rate and income equality significantly reduce the extent of corruption.

A potential source of concern is the incidence of omitted variable. The results may reflect the influence of time invariant variables not included in the regressions and that may affect corruption and democracy and economic freedom. Column (3) deals with this possibility by controlling period effects with 12 regional dummies, and column (4) controls for country and period fixed effects (FE). In both the cases, despite varying magnitude of the coefficients of PLS results (columns (1) and (2)), all coefficients have the same sign. Controlling for the fixed effect, the estimated democracy and interaction term coefficients are both significant, but the economic freedom coefficient is not statistically significant. We also estimate the random effect (column (5)) to capture the influence of unobserved factors that may produce heterogeneity across the countries, the result remains same. ${ }^{6}$

\section{[TABLE 1 ABOUT HERE]}

In order to interpret the impact of interaction effects of democracy and economic freedom on corruption the partial effects are estimated based on equations (2a) and (2b). ${ }^{7}$ Columns (6) and (7) in Table 2 report the results of partial effect of democracy on corruption at different levels of economic freedom (i.e. 0 to 10 ) with respect to two different estimation methods (i.e. PLS and FE). Both the results show that democracy increases corruption when the level of economic freedom is very low; yet once past the threshold point (i.e. between 4 and 5), corruption is substantially lower as the economy becomes more democratic. The threshold point is where economic freedom index is between 4 and 5 . Also, it is worth noting that, according to the FE result, the effect of democracy is significant only when the degree of economic freedom is either very low (2 or less) or very high (7 or higher) but in opposite

\footnotetext{
${ }^{6}$ See Bohara et al. (2004) for details.

${ }^{7}$ We estimate the model using the following form:$$
\mathrm{CPI}_{\mathrm{i}, \mathrm{t}}=\alpha_{0}+\delta_{1} \mathrm{DEMO}_{\mathrm{i}, \mathrm{t}}+\delta_{2} \mathrm{EF}_{\mathrm{i}, \mathrm{t}}+\beta_{3}\left(\mathrm{DEMO}_{\mathrm{i}, \mathrm{t}}-\mu_{1}\right) *\left(\mathrm{EF}_{\mathrm{i}, \mathrm{t}}-\mu_{2}\right)+\beta_{4} \log (\mathrm{RGDP})_{\mathrm{i}, \mathrm{t}}+\beta_{5} \mathrm{GINI}_{\mathrm{it}}
$$$$
+\beta_{6} \mathrm{UNEM}_{\mathrm{i}, \mathrm{t}}+\beta_{7} \mathrm{ALR}_{\mathrm{i}, \mathrm{t}}+\varepsilon_{\mathrm{i}, \mathrm{t}}
$$

where $\mu_{1}$ and $\mu_{2}$ take values from 0 to 10 . The coefficient $\delta_{1}$ measures the partial effect of democracy on corruption when $\mu_{2}$ takes the value from 0 to 10 for economic freedom index. Coefficient $\delta_{2}$ reports similar interpretation as $\delta_{1}$. See Wooldridge (2006, pp. 204-206) for details.
} 
directions. This suggests that democracy is a cure for corruption but only in the right environment. In contrast, when economic freedom is almost non-existent democracy may increase corruption.

Columns (8) and (9) show that economic freedom alleviates corruption in any political environment yet it becomes more effective when the level of democracy increases. Columns (6) and (8) are diagrammatically represented in Figure 1a and Figure 1b. It is obvious that economic freedom is more effective in combating corruption. Some observations regarding the country-specific examples can be seen in various cases. First, if economic freedom already exists in a country then democratization will accelerate the process of combating corruption, for example an increase in civil liberties and press freedom in China is seen to reduce the level of corruption from 7.8 in 1995 to 6.6 in $2004 .^{8}$ Second, if democracy already exists in a country then economic liberalization increases corruption at the early stages of transformation. For example, in the case of India, which has been a democracy for about sixty years, it is seen as quite corrupt even though economic liberalization started in 1991. Third, the countries seen as least corrupt are those known to be highly democratic and enjoy high levels of economic freedom, e.g. Canada, Denmark, New Zealand and other developed nations.

\section{[TABLE 2 ABOUT HERE]}

\section{[FIGURE 1a and FIGURE 1b ABOUT HERE]}

\section{Conclusion}

This paper empirically assesses the impact that democracy and economic freedom have on the prevalence of corruption and the interactive effects in 100 countries. The result shows that interaction effect of democracy and economic freedom has a significant impact on controlling corruption. The results remain robust under alternative panel estimations. For the partial effects result, democracy increases corruption when the level of economic freedom is very low. However, once past a threshold level corruption is substantially lower in a full mature democracy. As the results also reflect that economic freedom accelerates the process

\footnotetext{
${ }^{8}$ High value of CPI indicates high level of corruption.
} 
of combating corruption in the presence of democracy, therefore economic freedom first then democracy is vital for reducing corruption.

\section{References}

Acemoglu, D., Verdier, T., 2000. The choice between market failures and corruption. American Economic Review, 90, 194-211.

Ades, A., Tella, R. D., 1999. Rents, competition, and corruption. The American Economic Review, 89, 982-993.

Barro, R. J., 1999. Determinants of democracy. Journal of Political Economy, 107, S158S183.

Bohara, A. K., Mitchell, N. J., Mittendorff, C. F., 2004. Compound democracy and the control of corruption: a cross-country investigation. The Policy Studies Journal, 32, 481-499.

Chowdhury, S. K., 2004. The effect of democracy and press freedom on corruption: an empirical test. Economic Letters, 85, 93-101.

Emerson, P. M., 2006. Corruption, competition and democracy. Journal of Development Economics, 81, 193-212.

Fisman, R., Gatti, R., 2002. Decentralization and corruption: Evidence across countries. Journal of Public Economics, 83, 325-345.

Goel, R. K., Nelson, M. A., 2005. Economic freedom versus political freedom: cross-country influences on corruption. Australian Economic Papers, 44, 121-133.

Krueger, A. O., 1974. The political economy of the rent-seeking society. American Economic Review, 64, 291-303.

Larrain, F. B., Tavares, J., 2004. Does foreign direct investment decrease corruption? Cuadernos de Economia, 41, 217-230.

Mauro, P., 1997. Why worry about corruption? International Monetary Fund, Economic Issues, 6.

Rose-Ackerman, S., 1978. Corruption: study of political economy. Academic Press, New York.

Shen, C., Williamson, J. B., 2005. Corruption, democracy, economic freedom, and state strength: a cross-national analysis. International Journal of Comparative Sociology, 46, 327-345.

Shleifer, A., Vishny, R. W., 1993. Corruption. Quarterly Journal of Economics, 108, 599-617.

Tavares, J., Wacziarg, R., 2001. How democracy affects growth. European Economic Review, 45, 1341-1378.

Treisman, D., 2000. The causes of corruption: a cross-national study. Journal of Public Economics, 76, 399-457.

Vanhanen, T., 2000. A new dataset for measuring democracy, 1810-1998. Journal of Peace Research, 37, 251-265.

Wooldridge, J. M., 2006. Introductory econometrics: a modern approach, 3e. Thomson SouthWestern, Ohio. 
Table 1 Interaction effects of democracy and economic freedom on corruption: panel estimation

\begin{tabular}{|c|c|c|c|c|c|}
\hline & (1) & (2) & (3) & (4) & (5) \\
\hline DEMO & $\begin{array}{l}0.463 * * * \\
(0.061)\end{array}$ & $\begin{array}{l}0.435 * * * \\
(0.055)\end{array}$ & $\begin{array}{l}0.104^{*} \\
(0.061)\end{array}$ & $\begin{array}{l}0.152 * * \\
(0.064)\end{array}$ & $\begin{array}{l}0.092 \\
(0.058)\end{array}$ \\
\hline $\mathrm{EF}$ & $\begin{array}{l}-0.721 * * * \\
(0.036)\end{array}$ & $\begin{array}{l}-0.465^{* * * *} \\
(0.039)\end{array}$ & $\begin{array}{l}-0.471^{* * *} \\
(0.040)\end{array}$ & $\begin{array}{l}-0.020 \\
(0.049)\end{array}$ & $\begin{array}{l}-0.089 * * \\
(0.043)\end{array}$ \\
\hline DEMO*EF & $\begin{array}{l}-0.098^{* * *} \\
(0.009)\end{array}$ & $\begin{array}{l}-0.085 * * * \\
(0.008)\end{array}$ & $\begin{array}{l}-0.019 * * \\
(0.011)\end{array}$ & $\begin{array}{l}-0.033^{* * *} \\
(0.010)\end{array}$ & $\begin{array}{l}-0.029 * * * \\
(0.009)\end{array}$ \\
\hline Log(RGDP) & & $\begin{array}{l}-0.884 * * * \\
(0.079)\end{array}$ & $\begin{array}{l}-0.825^{* * *} \\
(0.089)\end{array}$ & $\begin{array}{l}-0.456^{*} \\
(0.259)\end{array}$ & $\begin{array}{l}-0.842^{* * *} \\
(0.135)\end{array}$ \\
\hline Gini index & & $\begin{array}{l}0.028 * * * \\
(0.005)\end{array}$ & $\begin{array}{l}0.045^{* * *} \\
(0.006)\end{array}$ & $\begin{array}{l}0.118^{* * *} \\
(0.010)\end{array}$ & $\begin{array}{l}0.097^{* * *} \\
(0.008)\end{array}$ \\
\hline Unemployment & & $\begin{array}{l}0.017 * * * \\
(0.005)\end{array}$ & $\begin{array}{l}0.019 * * * \\
(0.004)\end{array}$ & $\begin{array}{l}0.002 \\
(0.008)\end{array}$ & $\begin{array}{l}0.014^{* *} \\
(0.006)\end{array}$ \\
\hline Literacy rate & & $\begin{array}{l}0.029 * * * \\
(0.003)\end{array}$ & $\begin{array}{l}-0.004 \\
(0.004)\end{array}$ & $\begin{array}{l}-0.031^{* * *} \\
(0.012)\end{array}$ & $\begin{array}{l}0.008 \\
(0.007)\end{array}$ \\
\hline Latin America & & & $\begin{array}{l}1.005^{* * *} \\
(0.378)\end{array}$ & & \\
\hline Middle East & & & $\begin{array}{l}0.39 \\
(0.372)\end{array}$ & & \\
\hline East Asia & & & $\begin{array}{l}1.924 * * * \\
(0.419)\end{array}$ & & \\
\hline South East & & & $1.067 * * *$ & & \\
\hline Asia & & & $(0.385)$ & & \\
\hline South Asia & & & $\begin{array}{l}1.113^{* * *} \\
(0.399)\end{array}$ & & \\
\hline Eastern Europe & & & $\begin{array}{l}2.076^{* * *} \\
(0.394)\end{array}$ & & \\
\hline Central Asia & & & $\begin{array}{l}1.426 * * * \\
(0.422)\end{array}$ & & \\
\hline Africa & & & $\begin{array}{l}-0.213 \\
(0.372)\end{array}$ & & \\
\hline Western & & & $0.844^{* *}$ & & \\
\hline Europe & & & $(0.421)$ & & \\
\hline Northern & & & -0.419 & & \\
\hline Europe & & & $(0.443)$ & & \\
\hline North America & & & $\begin{array}{l}-0.032 \\
(0.483)\end{array}$ & & \\
\hline Australasia & & & $\begin{array}{l}-0.56 \\
(0.496)\end{array}$ & & \\
\hline Constant & $\begin{array}{l}9.563 * * * \\
(0.145)\end{array}$ & $\begin{array}{l}11.91^{* * *} \\
(0.659)\end{array}$ & $\begin{array}{l}12.523^{* * *} \\
(0.866)\end{array}$ & $\begin{array}{l}7.932^{* * *} \\
(2.512)\end{array}$ & $\begin{array}{l}8.974 * * * \\
(1.101)\end{array}$ \\
\hline $\begin{array}{l}\text { Number of } \\
\text { observations }\end{array}$ & 981 & 978 & 978 & 978 & 978 \\
\hline Adj $R$-squared & 0.72 & 0.78 & 0.84 & 0.96 & 0.33 \\
\hline
\end{tabular}


Table 2 Partial effects of democracy and economic freedom on corruption

\begin{tabular}{|c|c|c|c|c|}
\hline Level & $\begin{array}{l}\delta_{1} \text { (Panel } \\
\text { least square) } \\
(6) \\
E f=1,2 . .10\end{array}$ & $\begin{array}{l}\delta_{1} \text { (Fixed } \\
\text { effects) } \\
(7) \\
\text { Ef }=1,2 . .10\end{array}$ & $\begin{array}{l}\delta_{2} \text { (Panel least } \\
\text { square) } \\
(8) \\
\text { Demo }=1,2.10\end{array}$ & $\begin{array}{l}\delta_{2} \text { (Fixed } \\
\text { effects) } \\
(9) \\
\text { Demo=1,2.10 }\end{array}$ \\
\hline 0 & $\begin{array}{l}0.436^{* * *} \\
(0.055)\end{array}$ & $\begin{array}{l}0.154^{* * *} \\
(0.064)\end{array}$ & $\begin{array}{l}-0.464^{* * *} \\
(0.039)\end{array}$ & $\begin{array}{l}-0.013 \\
(0.049)\end{array}$ \\
\hline 1 & $\begin{array}{l}0.352^{* * *} \\
(0.047)\end{array}$ & $\begin{array}{l}0.12^{* *} \\
(0.056)\end{array}$ & $\begin{array}{l}-0.549^{* * *} \\
(0.037)\end{array}$ & $\begin{array}{l}-0.047 \\
(0.043)\end{array}$ \\
\hline 2 & $\begin{array}{l}0.267^{* * *} \\
(0.041)\end{array}$ & $\begin{array}{l}0.086^{*} \\
(0.048)\end{array}$ & $\begin{array}{l}-0.634^{* * *} \\
(0.0369)\end{array}$ & $\begin{array}{l}-0.08^{* *} \\
(0.04)\end{array}$ \\
\hline 3 & $\begin{array}{l}0.183^{* * *} \\
(0.034)\end{array}$ & $\begin{array}{l}0.053 \\
(0.041)\end{array}$ & $\begin{array}{l}-0.718^{* * *} \\
(0.039)\end{array}$ & $\begin{array}{l}-0.114^{* * *} \\
(0.039)\end{array}$ \\
\hline 4 & $\begin{array}{l}0.098^{* *} \\
(0.028)\end{array}$ & $\begin{array}{l}0.019 \\
(0.036)\end{array}$ & $\begin{array}{l}-0.803^{* * *} \\
(0.042)\end{array}$ & $\begin{array}{l}-0.147^{* * *} \\
(0.041)\end{array}$ \\
\hline 5 & $\begin{array}{l}-0.013 \\
(0.023)\end{array}$ & $\begin{array}{l}-0.014 \\
(0.034)\end{array}$ & $\begin{array}{l}-0.887^{* * *} \\
(0.046)\end{array}$ & $\begin{array}{l}-0.181^{* * *} \\
(0.046)\end{array}$ \\
\hline 6 & $\begin{array}{l}-0.071^{* * *} \\
(0.020)\end{array}$ & $\begin{array}{l}-0.048 \\
(0.035)\end{array}$ & $\begin{array}{l}-0.972^{* * *} \\
(0.052)\end{array}$ & $\begin{array}{l}-0.215^{* * *} \\
(0.052)\end{array}$ \\
\hline 7 & $\begin{array}{l}-0.156^{* * *} \\
(0.021)\end{array}$ & $\begin{array}{l}-0.082^{* *} \\
(0.039)\end{array}$ & $\begin{array}{l}-1.056^{* * *} \\
(0.058)\end{array}$ & $\begin{array}{l}-0.248^{* * *} \\
(0.059)\end{array}$ \\
\hline 8 & $\begin{array}{l}-0.240^{* * *} \\
(0.025)\end{array}$ & $\begin{array}{l}-0.115^{* * *} \\
(0.045)\end{array}$ & $\begin{array}{l}-1.141^{* * *} \\
(0.064)\end{array}$ & $\begin{array}{l}-0.282^{* * *} \\
(0.067)\end{array}$ \\
\hline 9 & $\begin{array}{l}-0.325^{* * *} \\
(0.03)\end{array}$ & $\begin{array}{l}-0.149^{* * *} \\
(0.052)\end{array}$ & $\begin{array}{l}-1.226^{* * *} \\
(0.07)\end{array}$ & $\begin{array}{l}-0.315^{* * *} \\
(0.076)\end{array}$ \\
\hline 10 & $\begin{array}{l}-0.409^{* * *} \\
(0.037)\end{array}$ & $\begin{array}{l}-0.182^{* * *} \\
(0.06)\end{array}$ & $\begin{array}{l}-1.310^{* * *} \\
(0.078)\end{array}$ & $\begin{array}{l}-0.349^{* * *} \\
(0.085)\end{array}$ \\
\hline
\end{tabular}

Standard errors are in parenthesis. ${ }^{* * *}, * *, *$ indicate the level of significance at the $1 \%, 5 \%$ and $10 \%$, respectively. 
Figure 1a Partial effects of democracy on corruption

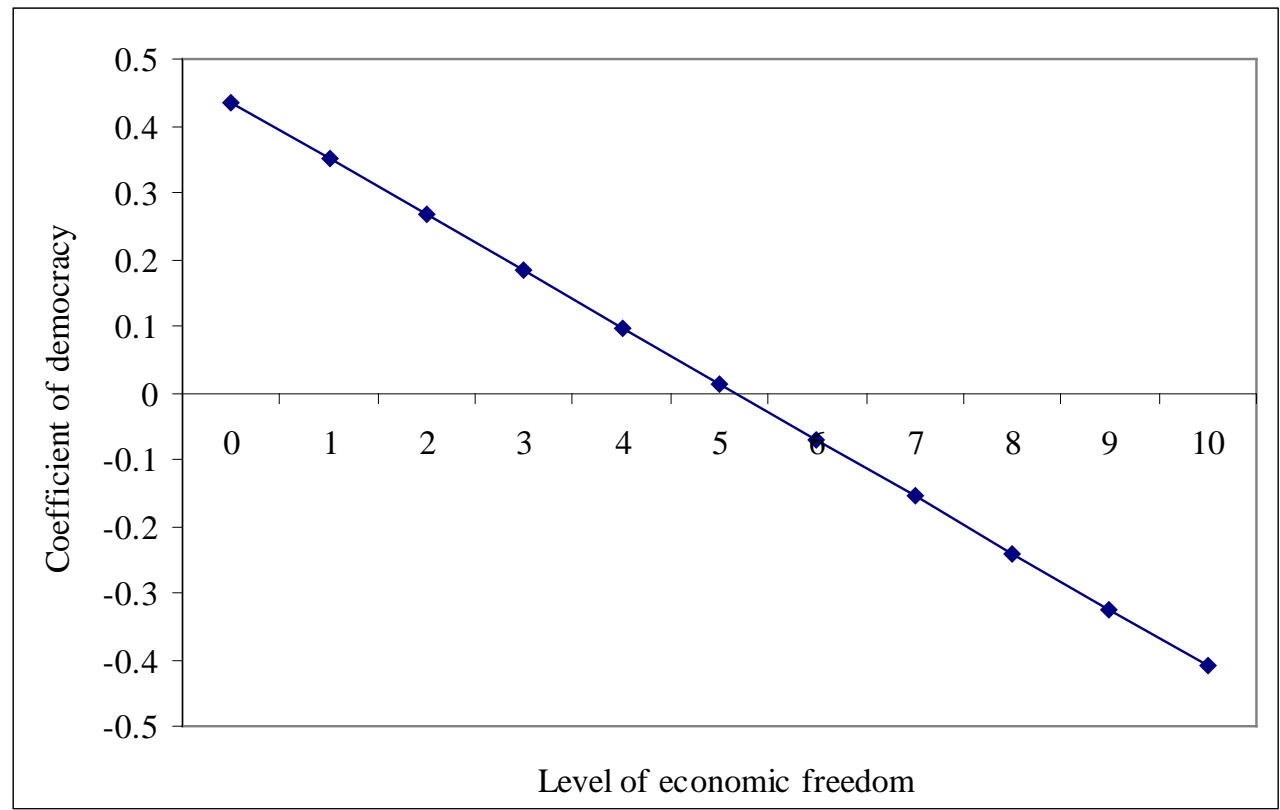

Figure 1b Partial effects of economic freedom on corruption

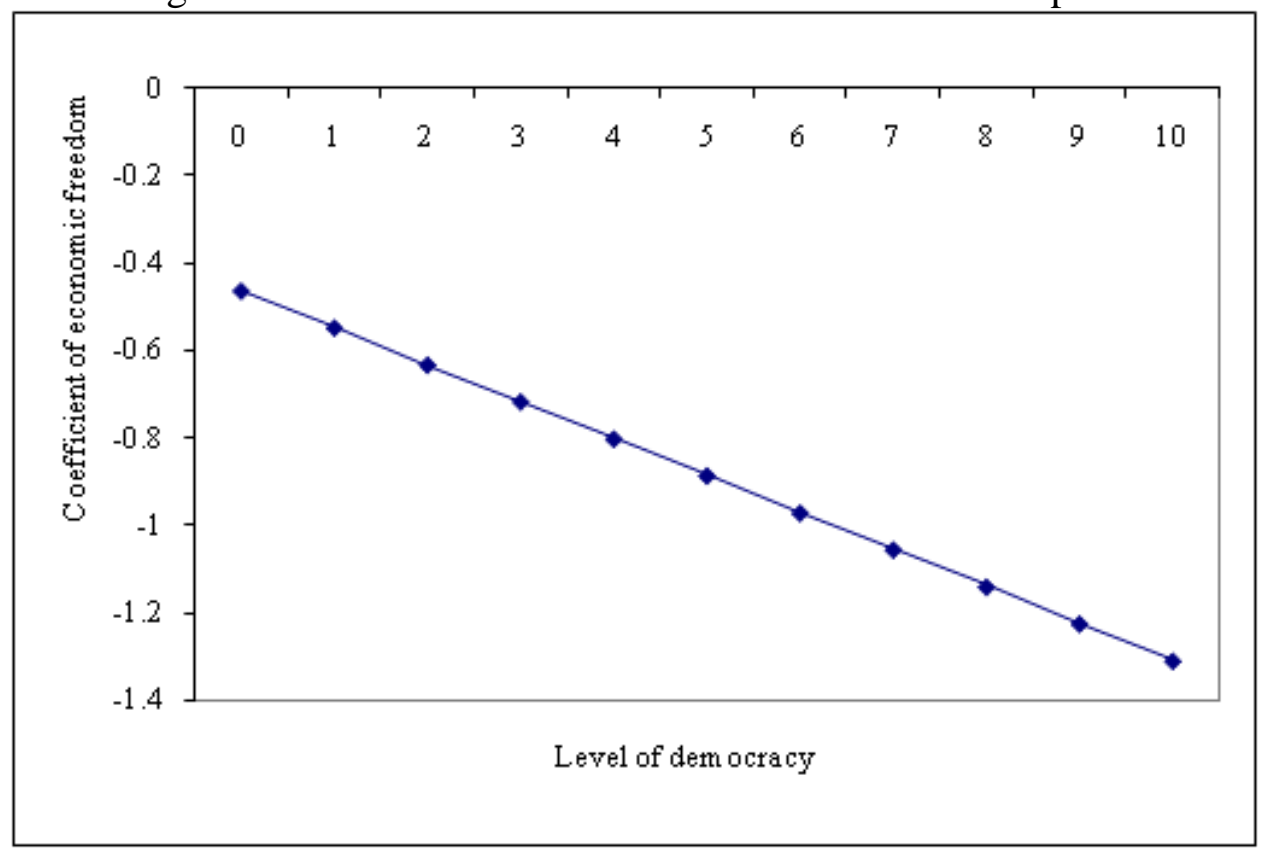

